\title{
Lexicographic Training at the Bureau of the Woordeboek van die Afrikaanse Taal
}

\author{
W.F. Botha and E. Botha, \\ Bureau of the Woordeboek van die Afrikaanse Taal, \\ Stellenbosch, South Africa
}

Abstract: Since 1995, the Bureau of the WAT has developed several training courses for students and other persons interested in gaining insight into and practical experience of the planning compilation and management of a dictionary. This article summarizes the courses offered.

Keywords: GENERAL LEXICOGRAPHY, COMPUTER LEXICOGRAPHY, CO-OPERATVE TRAINING, DICTIONARY TYPOLOGY, DICTIONARY PLANNING, DICTIONARY COMPILATION, DICTIONARY MANAGEMENT

Opsomming: Leksikografiese opleiding by die Buro van die Woordeboek van die Afrikaanse Taal. Die Buro van die WAT het sedert 1995 verskeie kursusse ontwikkel vir studente en ander persone wat daarin geïnteresseerd is om insig en praktiese ervaring te verkry in die beplanning, samestelling en bestuur van 'n woordeboek. Hierdie artikel gee 'n opsomming van die kursusse wat aangebied word.

Sleutelwoorde: ALGEMENE LEKSIKOGRAFIE, REKENAARLEKSIKOGRAFIE, KOÖPERATIEWE OPLEIDING, WOORDEBOEKTIPOLOGIE, WOORDEBOEKBEPLANNING, WOORDEBOEKSAMESTELLING, WOORDEBOEKBESTUUR

\section{Introduction}

One of the consequences of the strategic planning of the Bureau of the WAT was the development of an in-service training course. The course, which was aimed at the rapid development of the lexicographical skills of new staff members, proved to be very successful. As the idea of co-operative lexicography gained momentum at the Bureau, a training course for both practising lexicographers and persons interested in lexicography from outside the Bureau was designed in 1995. This led to the development of other training courses. The Bureau currently offers the following:

- a ten-day training course in general and computer lexicography and in the planning and manigement of a lexicographic project, offered during March and September,

- a co-operative training course for language practitioner students from technikons, 
a co-operative training course for students in lexicography and for lecturers who wish to gain practical experience of dictionary-making, lectures dealing mainly with dictionary typology and the dictionarymaking process.

2. Course in general and computer lexicography, and in the planning and management of a lexicographic project

\subsection{Background}

This course was first offered in 1995, and since then annually during March and September. Practising and prospective lexicographers, students and lecturers have attended the course. Attendants have come from almost all the provinces of South Africa, and also from as far as Namibia, Angola, Gabon, Zambia and Tanzania. Among the participants have been members of the isiXhosa, the isiZulu and the Sepedi Dictionary Projects, lecturers and students of the Soweto Campus of Vista University, the University of the North, the University of Venda, the University of Durban-Westville, the Technikon Northern Gauteng and members of the Language Services of the Northern Province. In 1997 two of the Bureau's staff members also offered a course at the Centre International des Civilisations Bantu (Ciciba) in Libreville, Gabon. The attendants represented several African countries.

The different components of the course are offered by staff members of the Bureau who specialize in a particular field of the dictionary-making process, such as general lexicography, computer lexicography, planning and management, and typesetting. It covers the theoretical and practical aspects of dictionary making and a wide range of topics in computer lexicography relevant to editorial and management staff of lexicographic projects. Attendants participate by identifying and examining different facets of the planning and management of a dictionary project. They are expected to do some reading on the topics treated, join group discussions and do practical exercises.

The course is structured in such a way that simple topics are introduced before more advanced ones. Consequently, there is enough variety and stimulation to keep participants interested and actively involved.

Since feedback from the participants is very important to the Bureau, evaluation forms are completed at the end of the course. This feedback has contributed to the evolution of the course over the past four years, and has for instance led to more time being allocated to the component dealing with computer lexicography.

A certificate of attendance detailing the topics covered in the training is presented to each participant upon completion of the course. 


\subsection{General lexicography}

The first component of the course covers many aspects of the theory of dictionary making. However, the aim of the course is the practical implementation of the theory of lexicography. Consequently much time is devoted to practical lexicography. The focus of the course is on descriptive dictionaries.

All participants have access to computers during the practical side of this component. A series of exercises guide them towards the compilation of dictionary articles using a template of tags. Participants with little or no computer experience receive personal attention from the presenters and progress at their own pace.

The course is well-documented and notes are made available to the participants during the course. The medium of instruction is English or Afrikaans, or both of these languages.

The needs of each group of participants are taken into consideration during the presentation of the course, thus the course has a dynamic character. Since the number of participants is usually limited to no more than six people per session, there is an opportunity for interaction between trainer and participant.

The following themes are covered in the component on general lexicography:

- Introduction

target user

dictionary typology

data collection

macro- and microstructure

types of information in a dictionary

diachrony and synchrony

lexicography, lexicology and metalexicography

- Criteria for inclusion

- Different kinds of lemmas as dictionary entries

- Labelling

- Dealing with meaning

polysemic versus homonymic lemmas

arrangement of polysemic distinctions

different kinds of definitions

general principles of definition

dealing with insulting and sensitive lexical items

- Grammatical information and its presentation

- Pronunciation

- Editing 


\section{Computer lexicography}

The contents of the computer lexicography component is changed annually to keep abreast of developments in computer technology, software and computer lexicography.

This component primarily covers matters of relevance to editorial and management staff of lexicographic projects in a general and nonspecialist manner. Issues such as the benefits of computerization, networks, hardware and software considerations, training and support are covered. The Bureau's system serves to illustrate some of these topics, and possible improvements or alternatives to the Bureau's system are also discussed.

Particular attention is given to language material collection and editorial processing. Some basic principles of database and corpus design and their use are discussed. The making of structured manuscript in a database and tagged text environment is also dealt with.

Participants have the opportunity to gain hands-on experience in manuscript making in a tagged text dictionary-making system. Electronic dictionaries on CD-ROM and the Internet are also demonstrated, as well as corpus-processing and concordancing tools.

A handbook containing exercises and a reading list is provided. Sample software and further reading matter are also provided, and participants can suggest how this component may be improved.

The Bureau has also developed prototype editorial manuscript-making systems for dictionary projects, together with manuals.

Below is a more detailed list of the topics covered:

\section{- Language material collection policy and techniques \\ - Compilation of a database and corpus \\ - Systems analysis and design \\ - Structured text and SGML \\ - Desktop publishing \\ - Electronic resources}

\subsection{Planning and management of a lexicographic project}

The component dealing with the planning and management of a lexicographic project is not only intended for managers, but for anybody interested in management. The particular needs of the trainees are taken into consideration.

Additional reading is expected from participants in order to stimulate discussion and to enable them to complete certain tasks.

Upon completion of this component, participants are able to formulate a goal, a mission, objectives, and medium- and long-term objectives for a dictionary project. 
The main themes covered in this component of the course are:

- Mission of the project

- Historical overview

- Strategic areas of focus

- Analysis of the environment restrictive factors in the internal/external environment supportive factors in the internal/external environment

- Scenario

- Assumptions regarding planning

- Strategic policy guidelines

- Objectives

ultimate goal

long-term objectives

medium-term objectives

goals

- Plan of action

- Values applicable to a lexicographic project

\section{Co-operative training of trainee language practitioners}

The Bureau of the WAT offers annual co-operative training courses to trainee language practitioner students as part of their practical training.

The students' existing skills and knowledge are utilized and developed over a period of ten weeks. The training is of a practical nature, and any special language skills are utilized and developed.

The students are introduced to many facets of dictionary-making, including language material collection, the verification thereof for editorial use, corpus building, lexicography, the making of dictionary manuscript, desktop publishing and the utilization of computer programs to create word-lists and to do word-frequency counts.

Students' are also assisted in developing their computer skills and in using the library, on-line library catalogues, the Internet, CD-ROMs and databases for language research and in dealing with language queries.

A certificate of attendance is presented to each student upon the completion of the course, detailing his/her activities.

This co-operative training course is possible as a result of an agreement between the Bureau and the tertiary institutions to which the students are affiliated.

\section{Co-operative training of students in lexicography}

Senior or postgraduate students in lexicography - both locally and from abroad - who wish to gain practical experience of dictionary-making, can be 
accommodated at the Bureau. They receive training according to their needs in selected components of the training courses discussed above. During the final stage the students have the opportunity to compile dictionary articles on computer, utilizing the data of the Bureau.

As with the training of language practitioner students, the training course is the result of an agreement between the Bureau and the universities to which the students are affiliated. The duration of the training is between four and ten weeks.

\section{Lectures dealing mainly with dictionary typology and the dictionary- making process}

Lectures dealing mainly with various traditional types of dictionaries and the dictionary-making process are presented on request. Groups of scholars, students and other interested persons attend these lectures. About six lectures are presented annually.

\section{Course fees and accommodation}

Course fees are determined according to the circumstances of the participants. Affordable accommodation can be arranged for participants. Details on exactly how the course fees are determined can be obtained from the Bureau.

\section{Information on the courses}

For further information on the training courses offered at the Bureau, Dr D.J. van Schalkwyk, Editor-in-chief can be contacted. The Bureau's particulars are:

Postal address: P.O. Box 245, Stellenbosch 7599

Telephone: (021) 8873113

Fax: (021) 8084336

E-mail: wat@maties.sun.ac.za

Website: http://www.sun.ac.za/wat/index.htm 